\author{
ANALISIS PENERAPAN AKUNTANSI PADA USAHA MIKRO KECIL DAN \\ MENENGAH \\ (STUDI KASUS PADA UMKM DI KOTA MAKASSAR)
}

\title{
ANALYSIS OF ACCOUNTING APPLICATION ON MICRO SMALL AND MEDIUM ENTERPRISES
}

\author{
Jafre-V2I1-01
}

\begin{abstract}
ABSTRAK
Akuntansi merupakan sistem informasi yang menghasilkan laporan kepada pihak-pihak yang berkepentingan mengenai aktivitas ekonomi dan kondisi perusahaan. Usaha Mikro Kecil dan Menengah (UMKM) sebagai penopang perekonomian bangsa sampai saat ini masih banyak yang belum menerapkan akuntansi dalam menjalankan usahanya. Penelitian ini bertujuan untuk mengetahui dan menganalisis penerapan akuntansi pada Usaha Mikro Kecil dan Menengah (UMKM) serta kendala-kendala yang dihadapi di dalamnya. Penelitian ini mengambil 100 UMKM di Kota Makassar dengan metode analisis deskriptif dengan menggunakan pendekatan kualitatif. Data yang dipergunakan adalah data primer yang diperoleh melalui hasil wawancara dan kuesioner. Hasil penelitian menunjukkan bahwa sebagian besar UMKM di Makassar sudah melakukan pencatatan atas penjualan, pembelian, biaya lainnya. Sedangkan pelaporan yang dibuat meliputi laporan penjualan, pembelian. Kendala yang menghambat UMKM dalam penerapan akuntansi antara lain adalah latar belakang pendidikan, belum pernah mengikuti pelatihan akuntansi dan belum ada kebutuhan terhadap penerapan akuntansi.
\end{abstract}

Kata Kunci : Akuntansi, Usaha Mikro Kecil dan Menengah (UMKM)

\section{ABSTRACT}

Accounting is an information system that generates reports to interested parties regarding the economic activity and condition of the company. Micro Small and Medium Enterprises (MSMEs) as the support of the nation's economy to date still many who have not applied accounting in running their business. This study aims to determine and analyze the application of accounting on Small and Medium Micro Enterprises (SMEs) and the constraints faced in it. This research took 100 UMKM in Makassar City with descriptive analysis method by using qualitative approach. The data used are primary data obtained through interviews and questionnaires. The results showed that most MSMEs in Makassar have recorded the sale, purchase, other costs. While the reporting made include sales reports, purchases. Constraints that hamper SMEs in the application of accounting, among others, is the educational background, has never been accounting training and there is no need for the application of accounting.

\section{Keywords: Accounting, Micro Small and Medium Enterprises (UMKM)}




\section{PENDAHULUAN}

Indonesia merupakan salah satu negara berkembang di Asia. Sebagai negara yang berkembang tentunya Indonesia memfokuskan akan pembangunan dan pertumbuhan ekonomi ke arah yang lebih baik agar bangsa indonesia tidak tertinggal dengan negara lain . Proses pembangunan ini, memberi pengaruh langsung kepada pertumbuhan dan perkembangan dunia usaha yang merupakan unit-unit ekonomi nasional.

Sejalan dengan perkembangan dunia usaha tersebut, maka banyak berdiri bentukbentuk usaha baik yang berskala kecil, menengah sampai berskala besar. Di era globalisasi saat ini, terutama di saat krisis global sedang melanda dunia diharapkan setiap bentuk usaha dituntut untuk bisa maju dan bertahan dalam menjalankan kegiatan usahanya.

Salah satu bentuk usaha yang memberikan kontribusi terhadap pertumbuhan ekonomi di Indonesia adalah UMKM (Usaha Mikro Kecil dan Menengah). Pesatnya perkembangan Usaha Mikro Kecil dan Menengah telah memberikan konstribusi yang penting dan besar bagi Indonesia dikutip dari Kementerian Koperasi dan Usaha Kecil Menengah (UMKM) mencatat kontribusi sektor Usaha Mikro Kecil dan Menengah meningkat dari 57,84 persen menjadi 60,34 persen,tak hanya itu, sektor Usaha Mikro Kecil dan Menengah juga telah membantu penyerapan tenaga kerja di dalam negeri. Serapan tenaga kerja pada sektor Usaha Mikro Kecil dan Menengah tumbuh dari 96,99 persen menjadi 97,22 persen dalam periode lima tahun terakhir. Karena itu, pemberdayadan pengembangan yang berkelanjutan perlu dilakukan agar Usaha Mikro Kecil dan Menengah tidak hanya tumbuh dalam jumlah tetapi juga berkembang dalam kualitas daya saing produknya. Pemberdayaan bidang Usaha Mikro Kecil dan Menengah menjadi sangat penting karena potensinya yang besar dalam menggerakkan kegiatan ekonomi masyarakat dan sekaligus menjadi tumpuan sumber pendapatan sebagian besar masyarakat dalam meningkatkan kesejahteraanya. 
Kontribusi yang begitu besar diberikan oleh Usaha Mikro Kecil dan Menengah, maka diperlukan perhatian lebih untuk mengembangkan sekaligus mempertahankan keberadaan Usaha Mikro Kecil dan Menengah di Indonesia karena pada kenyataannya Usaha Mikro Kecil dan Menengah juga memiliki kelemahan yang biasanya terjadi pada pengelolaan keuangan dan manajemen yang belum tertata dengan baik serta kurangnya modal usaha. Dalam hal ini Pemerintah sudah mencoba membantu mengatasi kendala yang dihadapi oleh sebagian besar Usaha Mikro Kecil dan Menengah seperti melakukan pembinaan dan pemberian kredit. Namun muncul permasalahan baru pada para Usaha Mikro Kecil dan Menengah yang diharuskan menyertakan laporan keuangan sebagai syarat mengajukan pinjaman kepada pihak bank. Karena dari pihak perbankan sendiri tidak ingin mengambil resiko dalam penyaluran kredit bagi usaha kecil dan menengah lantaran perbankan tidak mengetahui perkembangan usaha tersebut.

Secara umum pelaku Usaha Mikro Kecil dan Menengah belum dapat membuat laporan keuangan karena mereka tidak dibiasakan untuk melakukan pencatatan dan penyusunan laporan keuangan sesuai dengan standar siklus akuntansi yang berlaku, mereka hanya mencatat jumlah uang yang diterima dan jumlah uang yang dikeluarkan,jumlah barang yang dibeli dan dijual, dan jumlah piutang atau utang namun pencatatan itu hanya sebatas pengingat saja dan tidak dengan siklus akuntansi yang berlaku menurut Srikandi dan Setyawan (2007) para pelaku Usaha Mikro Kecil dan Menengah belum menerapkan siklus akuntansi dengan benar dalam usaha mereka dimana mereka beranggapan bahwa pengetahuan mereka yang terbatas mengenai akuntansi menjadikan para pelaku Usaha Mikro Kecil dan Menengah menganggap menerapkan siklus akuntansi kedalam usaha mereka adalah hal yang rumit dan sulit .

Dalam hal pelaporan keuangan Ikatan Akuntan Indonesia sebenarnya telah menerbitkan Standar Akuntansi Keuangan untuk Entitas Tanpa Akuntabilitas Publik (SAKETAP). Dengan 
menerapkan Standar ini, pihak perbankan tentu akan merespon positif sehingga memudahkan perbankan dalam menilai kelayakan bisnis usaha kecil dan menengah dalam memperoleh bantuan kredit pengembangan usaha. Namun ternyata SAK ETAP masih belum dipahami karena disebabkan oleh beberapa faktor antara lain latar belakang pendidikan,selain itu disebabkan pula oleh sosialisasi ataupun pelatihan dari pihak pemerintah maupun lembaga yang membawahi Usaha Mikro Kecil dan Menengah masih kurang maksimal,sehingga pemahaman akan pentingnya laporan keuangan masih belum dipahami oleh pelaku Usaha Mikro Kecil dan Menengah.

Penerapan siklus akuntansi dalam suatu usaha memiliki peranan penting. Siklus akuntansi dimulai dari terjadinya transaksi, sampai penyiapan laporan keuangan pada akhir suatu periode. Walaupun dampak dari diabaikannya pengelolaan keuangan tidak terlihat secara jelas, namun tanpa penerapan siklus akuntansi yang efektif, usaha yang memiliki prospek yang cerah dapat menjadi bangkrut. Melalui penerapan siklus akuntansi yang baik, diharapkan sebuah pelaku Usaha Mikro Kecil dan Menengah dapat mengetahui bagaimana perkembangan dan kesehatan usahanya, bagaimana struktur modalnya, berapa keuntungan yang diperoleh usahanya pada suatu periode tertentu. Hal ini sangat penting agar pelaku Usaha Mikro Kecil dan Menengah dapat menilai secara pasti kinerja dan kesehatan usahanya.

Melihat begitu pentingnya peranan penerapan siklus akuntansi bagi sebuah Usaha Mikro Kecil dan Menengah, maka penelitian ini berusaha untuk melakukan kajian terhadap penerapan siklus akuntansi dalam operasional usaha skala kecil dan menengah. Adapun perbedaan antara penelitian sebelumnya dengan penelitian yang dilakukan oleh peneliti yaitu pada penelitian ini berfokus untuk untuk mengetahui apakah para pelaku Usaha Mikro Kecil dan Menengah sudah menerapkan siklus akuntansi dengan benar. 


\section{Lokasi dan Rancangan Penelitian}

Penelitian ini dilakukan pada usaha kecil dan menengah di kota Makassar dengan memfokuskan terhadap kegiatan pengelolaan (siklus) akuntansinya, sehingga dapat diketahui sejauh mana para pelaku usaha kecil dan menengah menerapkan kaidah-kaidah siklus akuntansi dalam usahanya.

\section{Populasi dan Sampel}

Populasi dalam penelitian ini adalah usaha kecil dan menengah (UMKM) dikota Makassar yang berjumlah 12.860 UMKM (data Dinas Koperasi dan UMKM Kota Makassar Th. 2016). Dan untuk mendapatkan sampel yang dapat menggambarkan populasi, maka dalam penentuan sampel penelitian ini digunakan rumus (Sarwono, Jonathan, 2012: 24) sebagai berikut:

$$
\mathrm{n}=\frac{\mathrm{N}}{1+\mathrm{N} \mathrm{e}^{2}}
$$

Dimana:

n : ukuran sampel

$\mathrm{N}$ : ukuran populasi

e : persen kelonggaran ketidaktelitian karena kesalahan pengambilan sampel yang masih dapat ditolerir. Dari jumlah populasi tersebut dengan tingkat kelonggaran 10\%,

\section{Metode Pengumpulan Data}

Pengumpulan data yang dibutuhkan guna mendukung penelitian ini menggunakan metode survei kuesioner. Survei kuesioner merupakan metode survei dengan menggunakan kuesioner penelitian. Kuesioner penelitian ini diserahkan langsung kepada responden

\section{Metode Analisis Data}

Teknik analisis data yang digunakan dalam penelitian ini adalah menggunakan skala Guttman, yaitu untuk jawaban "Ya" diberikan skor satu, sedangkan untuk jawaban "Tidak" diberikan skor nol dengan ketentuan yang dikemukakan oleh Sugiyono (2004:90) mengenai skala Guttman, ketentuannya adalah sebagai berikut: 
¿Jawaban "Ya"

$\mathrm{x} 100 \%$

$\sum$ Jawaban Kuesioner

Keterangan :

$0.00-0.25=$ No association or low association (weak association)

$0.25-0.5=$ Moderately low association (moderately weak association)

0.51-0.75= Moderately high association (moderately strong association)

0.76-1 = High association (strong association) up to perfect association.

Berdasarkan kriteria tersebut, jika dikaitkan dengan penelitian dapat dijelaskan sebagai berikut:

a. $0 \%-25 \%$, berarti pelaku UMKM tidak menerapkan siklus akuntansi pada pengelolaan keuangan usahanya.

b. $26 \%$ - 50\%, berarti pelaku UMKM kurang menerapkan siklus akuntansi pada pengelolaan keuangan usahanya.

c. $51 \%$ - $75 \%$, berarti pelaku UMKM cukup menerapkan siklus akuntansi pada pengelolaan keuangan usahanya.

d. $76 \%$ - 100\%, berarti pelaku UMKM sangat menerapkan siklus akuntansi pada pengelolaan keuangan usahanya. Selanjutnya Data yang terkumpul diolah, diuji, dan dianalisis dengan Statistical Package for the Sosial Science (SPSS) Versi 22

\section{HASIL DAN PEMBAHASAN}

\section{Karakteristik Responden}

Dari gambar di atas dapat diketahui bahwa jumlah responden adalah 100 orang, dengan jumlah responden 62 orang (62\%) adalah wanita dan sisanya 38 orang (38\%) adalah pria. Apabila ditinjau dari tingkat pendidikan, maka dapat diketahui bahwa rata-rata pendidikan 
pengelola usaha mikro kecil dan menengah yang menjadi responden adalah SMA sebesar 34 orang (34\%), dan responden yang berpendidikan sampai SMP sebanyak 27 orang (27\%), sedangkan yang berpendidikan sampai SD adalah 20 orang (20\%) dan hanya terdapat 19 orang (19\%) responden yang berpendidikan Sarjana Dari hasil jawaban responden melalui kuesioner yang disebar ke 100 UMKM, diketahui sejauh mana pengertian dan pengetahuan para pelaku UMKM terhadap akuntansi pada umumnya dan siklus akuntansi pada khususnya

Tabel 4.1

\section{Responden mengenal istilah akuntansi}

$$
\mathbf{n}=\mathbf{1 0 0}
$$

\begin{tabular}{|l|l|l|}
\hline Mengenal istilah akuntansi & Frekuensi & Persentase \\
\hline Ya & 43 & $43 \%$ \\
\hline Tidak & 57 & $57 \%$ \\
\hline
\end{tabular}

Sumber : diolah dari angket,pertanyaan A

Dari tabel 4.1 diatas, diketahui bahwa responden yang tidak mengenal istilah akuntansi lebih mendominasi yaitu sekitar 53\% hal ini disebabkan oleh latar belakang pendidikan para responden yang $47 \%$ adalah SD dan SMP hal ini juga sejalan dengan penelitian yang dilakukan oleh Desy Yuliani dan Supriono (2016) yang mengatakan bahwa latar belakang pendidikan para pelaku UMKM sangat berpengaruh terhadap penerapan siklus akuntansi yang diterapkan pada usahanya.

Tabel 4.2

\section{Responden memiliki buku catatan pembukuan}

$$
\mathbf{n}=\mathbf{1 0 0}
$$

\begin{tabular}{|l|l|l|}
\hline Adanya buku catatan pembukuan & Frekuensi & Persentase \\
\hline Ya & 35 & $35 \%$ \\
\hline Tidak & 65 & $65 \%$ \\
\hline
\end{tabular}

sumber : diolah dari angket,pertanyaan B

Dari tabel diatas menunjukkan bahwa masih banyak pelaku UMKM yang tidak memiliki catatan pembukuan pada usaha sebanyak $65 \%$ menurut pelaku UMKM membuat buku catatan pembukuan dirasa belum dibutuhkan dalam usahanya. 
Tabel 4.3

Responden memahami catatan pembukuan/akuntansi

$\mathbf{n}=\mathbf{1 0 0}$

\begin{tabular}{|l|l|l|}
\hline $\begin{array}{l}\text { Memahami catatan } \\
\text { pembukuan/akuntansi }\end{array}$ & Frekuensi & Persentase \\
\hline Ya & 27 & $27 \%$ \\
\hline Tidak & 73 & $73 \%$ \\
\hline
\end{tabular}

sumber : diolah dari angket,pertanyaan C

Dari tabel diatas hanya sekitar $27 \%$ dari responden yang memahami catatan pembukuan /akuntansi. Hal ini terjadi karena tingakt pendidikan pelaku UMKM yanng rendah sehingga kurang memahami tentang pembukuan atau pencatatan.

Tabel 4.4

Responden memiliki laporan keuangan

$\mathrm{n}=\mathbf{1 0 0}$

\begin{tabular}{|l|l|l|}
\hline Memilik lapaoran keuangan & Frekuensi & Persentase \\
\hline Ya & 22 & $22 \%$ \\
\hline Tidak & 78 & $78 \%$ \\
\hline
\end{tabular}

sumber : diolah dari angket,pertanyaan D

Diliat dari tabel diatas $78 \%$ responden tidak memiliki laporan keuangan dan hanya $22 \%$ responden yang sudah memiliki laporan keuangan ini terjadi karena masih banyak para pelaku UMKM beranggapan kalau membuat laporan keuangan itu sangat sulit dan masih belum terlalu penting bagi usaha hal ini juga diutaran oleh Amanah (2012) dalam penelitiannya yang menyatakan banyak para pelaku UMKM tidak dapat membuat laporan keuangan selain sulit mereka juga merasa hal tersebut memelurkan keahlian khusus dalam membuat suatu laporan keuangan. 
Tabel 4.5

Responden melakukan pencatatan secara komputerisasi

$\mathbf{n}=\mathbf{1 0 0}$

\begin{tabular}{|l|l|l|}
\hline $\begin{array}{l}\text { Melakukan pencatatan secara } \\
\text { kompeterisasi }\end{array}$ & Frekuensi & Persentase \\
\hline Ya & 13 & $13 \%$ \\
\hline Tidak & 87 & $87 \%$ \\
\hline
\end{tabular}

sumber : diolah dari angket,pertanyaan $\mathrm{E}$

Dari tabel diatas hanya $13 \%$ responden yang melakukan pencatatan laporan secara komputerisasi dan sisanya masih dengan cara manual. Berdasarkan wawancara alasan pengeolola UMKM masih menggunakan pencatatan secara manual karena penggunaan komputer masih di anggap susah dan rumit sehingga memerlukan waktu untuk mempelajari secara mendalam sistem akan di gunakan

Tabel 4.6

Responden mempunyai buku kas masuk dan keluar atau catatan lainnya $\mathrm{n}=\mathbf{1 0 0}$

\begin{tabular}{|l|l|l|}
\hline $\begin{array}{l}\text { Mempunyai buku kas masuk } \\
\text { dan keluar atau catatan lainnya }\end{array}$ & Frekuensi & Persentase \\
\hline Ya & 42 & $42 \%$ \\
\hline Tidak & 58 & $58 \%$ \\
\hline
\end{tabular}

Sumber : diolah dari angket,pertanyaan F

Dari data diatas dapat diketahui hanya $42 \%$ responden yang mempunyai buku kas masuk dan keluar atau catatan lainnya dalam menjalakan usahanya itupun hanya dalam bentuk sederhana .

\section{Tabel 4.7}

Responden memahami manfaat dari laporan keuangan

$\mathbf{n}=\mathbf{1 0 0}$

\begin{tabular}{|l|l|l|l|}
\hline \multicolumn{1}{|c|}{$\begin{array}{c}\text { Memahami manfaat laporan } \\
\text { keuangan }\end{array}$} & Frekuensi & Persentase \\
\hline Ya & 26 & $26 \%$ \\
\hline Tidak & 74 & $74 \%$ \\
\hline
\end{tabular}


sumber : diolah dari angket,pertanyaan $\mathrm{G}$

Dari tabel diatas sebagian responden menjawab telah memahami manfaat dari laporan keuangan yaitu sebesar $26 \%$ dan sisanya $74 \%$ responden menjawab tidak memahami manfaat dari laporan keuangan.

Tabel 4.8

Responden mempunyai SDM yang sudah mencukupi

$\mathbf{n}=\mathbf{1 0 0}$

\begin{tabular}{|l|l|l|}
\hline $\begin{array}{l}\text { Mempunyai buku kas masuk } \\
\text { dan keluar atau catatan lainnya }\end{array}$ & Frekuensi & Persentase \\
\hline Ya & 29 & $29 \%$ \\
\hline Tidak & 71 & $71 \%$ \\
\hline
\end{tabular}

sumber : diolah dari angket,pertanyaan $\mathrm{H}$

Dari data diatas diketahui bahwa sumber daya manusia yang dimiliki oleh para pelaku UKM masih belum mencukupi terlihat hanya $29 \%$ saja yang merasa memiliki sumber daya manusia yang cukup dengan memiliki SDM atau tenaga kerja dengan kemampuan akuntansi sangat penting dalam suatu usaha karena dengan adanya tenaga kerja yang memahami akuntansi maka proses penerapan akuntansi dapat berjalan dengan baik.

Tabel 4.9

\section{Responden membuat nota penjualan}

$\mathrm{n}=\mathbf{1 0 0}$

\begin{tabular}{|l|l|l|}
\hline \multicolumn{1}{|c|}{ Membuat nota penjualan } & Frekuensi & Persentase \\
\hline Ya & 83 & $83 \%$ \\
\hline Tidak & 17 & $17 \%$ \\
\hline
\end{tabular}

sumber : diolah dari angket,pertanyaan I

Tabel 9 menunjukkan bahwa $83 \%$ responden membuat nota penjualan dalam menjalankan usahanya. Nota penjualan berfungsi sebagai alat untuk mengetahui banyaknya barang yang dibeli, jumlah barang yang dibeli, dan sebagai tanda terima pembayaran/kuitansi.

Tabel 4.10

\section{Responden membuat jurnal setiap melakukan transaksi}

$$
\mathbf{n}=\mathbf{1 0 0}
$$




\begin{tabular}{|c|c|c|}
\hline $\begin{array}{c}\text { Membuat jurnal setiap melakukan } \\
\text { transaksi }\end{array}$ & Frekuensi & Persentase \\
\hline Ya & 17 & $17 \%$ \\
\hline Tidak & 83 & $83 \%$ \\
\hline
\end{tabular}

sumber : diolahdari angket,pertanyaan J

Dari tabel 4.10 terlihat dari segi membuat jurnal setiap terjadinya transaksi, dari 100 responden hanya berbanding sedikit responden yang melakukan pencatatan yaitu sebesar (17\%) . Hasil ini memberikan kecenderungan bahwa masih banyak pelaku UMKM yang belum melakukan pencatatan saat terjadinya transaksi, dimana pencatatan merupakan tahap awal yang sangat mendasar dalam proses siklus akuntansi itu sendiri

Tabel 4.11

Responden memiliki bukti transaksi

$\mathbf{n}=\mathbf{1 0 0}$

\begin{tabular}{|c|c|c|}
\hline Memiliki bukti transaksi & Frekuensi & Persentase \\
\hline Ya & 49 & $49 \%$ \\
\hline Tidak & 51 & $51 \%$ \\
\hline
\end{tabular}

sumber : diolah dari angket,pertanyaan $\mathrm{K}$

Dari tabel diatas dapat dilihat bahwa hampir setengah dari responden memiliki bukti transaksi pada setiap transaksi usahanya. Sebesar $49 \%$ responden memiliki bukti transaksi untuk setiap transaksi usaha yang dilakukannya, sedangkan sisanya tidak memiliki bukti transaksi 
Tabel 4.12

Distribusi skor penerapan siklus akuntansi

\begin{tabular}{|c|c|c|c|c|}
\hline \multirow{2}{*}{$\begin{array}{c}\text { No } \\
\text { Pertanyaan : }\end{array}$} & \multicolumn{2}{|c|}{ Skor } & \multirow{2}{*}{ Jumlah } & Rata-rata \\
\cline { 2 - 3 } & Tidak & Ya & & 0,43 \\
\hline A & 57 & 43 & 43 & 0,35 \\
\hline B & 65 & 35 & 35 & 0,27 \\
\hline D & 73 & 27 & 27 & 0,22 \\
\hline E & 87 & 13 & 13 & 0,13 \\
\hline F & 58 & 42 & 42 & 0,42 \\
\hline G & 74 & 26 & 26 & 0,26 \\
\hline H & 71 & 29 & 29 & 0,29 \\
\hline I & 17 & 83 & 83 & 0,83 \\
\hline J & 83 & 17 & 17 & 0,17 \\
\hline K & 51 & 49 & 49 & 0,49 \\
\hline & & & & 0.35 \\
\hline
\end{tabular}

sumber : diolah dari data hasil angket dan kuesioner (2017)

Dari tabel 4.12 di atas, setelah memberikan skor dan menjumlahkan 11 pertanyaan yang terdapat pada aspek pengelolaan keuangan, dimana penulis memberikan skor 1 untuk setiap jawaban 'Ya' dan skor 0 untuk setiap jawaban 'Tidak', maka hasil rata-rata yang didapat adalah skor tertimbang sebesar 0.35 dimana mengacu pada Skala Guttman angka tersebut berada pada moderately low associaton(moderately weak association) yang menunjukkan bahwa penerapan siklus akuntansi melalui aspek pengelolaan keuangan pada usaha mikro kecil dan menengah dikota Makassar masih kurang.

\section{KESIMPULAN DAN SARAN}

Hasil penelitian menunjukan bahwa penerapan akuntansi oleh usaha kecil dan menengah di Kota Makassar masih kurang. Dari hasil skor tertimbang skala Guttman yaitu 0,35 dimana skala tersebut berada pada moderately low associaton(moderately weak association )yangmenunjukan rendahnya penerapan sistem akuntansipada Usaha Mikro Kecil dan Menengah (UMKM) di Kota Makassar. Minimnya penerapan akuntansi yang dilakukan oleh 
usaha kecil dan menengah dikarenakan kurangnya keinginan dari pelaku usaha kecil dan menengah untuk melakukan pencatatanatau pembukuan untuk usahanya, dikarenakan terlalu merepotkan untuk mencatat transaksi keuangan mereka. Dengan arti kata pelaku usaha mikro kecil dan menengah (UMKM ) tidak mempunyai motivasi atau keinginan untuk menjadi lebih baik di masa yang akan datang. Untuk mempermudah para pelaku usaha kecil dan menengah (UKMK) dalam melakukan usahanya diharapkan adanya bimbingan dan kerjasama dari pihak-pihak terkait terutama Dinas UMKM Kota Makassar dan LSM terkait untuk dapat membina dan memberikan pelatihan yang lebih intensif lagi bagi para pelaku usaha mikro kecil dan menengah(UMKM), agar usaha mereka jadi jauh lebih baikkedepannya. Dan diharapkan pula bagi para pelaku usaha mikro kecil dan menengah (UMKM) agar dapat menerapkan ilmu yang telah di berikan didalam menjalankan usahanya. 


\section{DAFTAR PUSTAKA}

Arif, Abubakar dan Wibowo. 2008. Akuntansi Keuangan Dasar I. Edisi 3. Jakarta: Grasindo

Belkaoui, Ahmed Riahi, 2011. Accounting Theory.Buku I.Edisi 5.Jakarta: Salemba Empat

Fansuri,2006.Analisis Perumusan dan Penerapan Sistem Akuntansi Pada UKM(Studi Kasus

UKM Ozy Aircraf Bogor).Skripsi. Bogor: Fakultas Ekonomi Manajemen, Institut Pertanian Bogor.

Ghozali, Imam. (2011). Aplikasi Analisis Multivariate Dengan Program IBM SPSS 20 edisi 6. Semarang: BP Universitas Diponegoro.

Kountur, Ronny, (2004), Metode Penelitian Untuk Penulisan Skripsi dan Tesis,Jakarta:Penerbit PPM

Puspa Ervilia (2009). Analisis Perumusan dan Penerapan Sistem Akuntansi Pada Usaha Kecil Menengah (Studi Kasus Waroeng Coklat Bogor).Skripsi. Bogor: Fakultas Ekonomi dan Manajemen, Institut Pertanian Bogor.

Saragih, Fitriani dan Surikayati (2015). Analisis Penerapan Akuntansi dan Kesesuaiannya dengan SAK ETAP pada UKM Medan Perjuangan. Fakultas Ekonomi Universitas Muhammadiyah Sumatera Utara.

Sari,Amanah.2013. Analisis Penerapan Pencatatan Akuntansi pada Usaha Kecil dan Menengah Binaan Dinas Koperasi UMKM Perindustrian dan Perdagangan. Kabupaten Lima Puluh Kota. Hal. 1-8.

Sanusi,Anwar. 2013. Metodologi Penelitian Bisnis.Cetakan Ketiga. Jakarta : Salemba Empat Seri.

Srikandi, Cut dan Aris Budi Setyawan. (2004). Analisis Penerapan Siklus Akuntansi pada Usaha Kecil Dan Menengah di Daerah Istimewa Yogyakarta. STIE Megarkencana.

Suharli, Michell, 2006. Akuntansi untuk Bisnis Jasa dan Dagang, Edisi Pertama, Graha Ilmu, Yogyakarta.

Sugiyono. (2010). Metode Penelitian Bisnis (Pendekatan Kuantitatif, Kualitatif dan R\&D). Bandung: Alfabeta

Sugiyono, Metode Penelitian Bisnis, penerbit Alfabeta, Bandung, 2004

Soemarso,S.R,2004. Akuntansi Suatu Pengantar.Buku I. Salemba Empat: Jakarta Sofyan Syafri Harahap, 2011, Teori Akuntansi, edisi revisi, Raja Grafindo Persada, Jakarta Sugiyono,2011.Metode Penelitian Kuantitatif, Kualitatif, dan R\&D. Bandung; AFABETA, Suwardjono,2009.Pengantar Akuntansi.Buku I. Edisi 3.Yogyakarta; BPFE Yogyakarta. Undang-Undang Nomor 20 tahun 2008 tentang UMKM 
Warren, Carl. S, James M. Reeve, Philip E. Fess, Aria Farahmita, Amanugrahani, Taufik Hendrawan, 2006. Pengantar Akuntansi. Buku I. Jakarta

Weygandt, Jerry.J, Donald E.Kieso, Paul.D.Kimmel, 2007.Akuntansi Suatu Pengantar,Edisi ke-7, Salemba Empat, Jakarta.

Yanti, 2014. Analisis Penerapan Akuntansi Pada Usaha KecilMenengah di Family Pisces. Skripsi. Sumatera Barat: Fakultas Ekonomi Universitas Muhamadiyah.

Yuliana dan supriono (2016) Analisis penerapan siklus akuntansi pada usaha kecil dan menengah di kabupaten Purworejo 